\title{
PSYCHOLOGICA
}

\section{Transição e ajustamento de reclusos ao estabelecimento prisional}

Autor(es): $\quad$ Novais, Filipa Alexandra Grilo; Ferreira, Joaquim Armando; Santos, Eduardo Ribeiro dos

Publicado por: Imprensa da Universidade de Coimbra

URL

persistente: URI:http://hdl.handle.net/10316.2/3470

DOI: ～DOI:http://dx.doi.org/10.14195/1647-8606_52-2_9

Accessed : $\quad$ 26-Apr-2023 11:42:39

A navegação consulta e descarregamento dos títulos inseridos nas Bibliotecas Digitais UC Digitalis, UC Pombalina e UC Impactum, pressupõem a aceitação plena e sem reservas dos Termos e Condições de Uso destas Bibliotecas Digitais, disponíveis em https://digitalis.uc.pt/pt-pt/termos.

Conforme exposto nos referidos Termos e Condições de Uso, o descarregamento de títulos de acesso restrito requer uma licença válida de autorização devendo o utilizador aceder ao(s) documento(s) a partir de um endereço de IP da instituição detentora da supramencionada licença.

Ao utilizador é apenas permitido o descarregamento para uso pessoal, pelo que o emprego do(s) título(s) descarregado(s) para outro fim, designadamente comercial, carece de autorização do respetivo autor ou editor da obra.

Na medida em que todas as obras da UC Digitalis se encontram protegidas pelo Código do Direito de Autor e Direitos Conexos e demais legislação aplicável, toda a cópia, parcial ou total, deste documento, nos casos em que é legalmente admitida, deverá conter ou fazer-se acompanhar por este aviso.

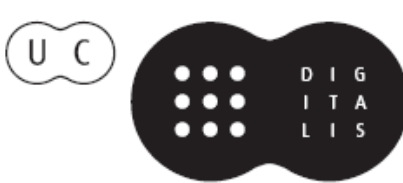




\section{NÚMERO 52}

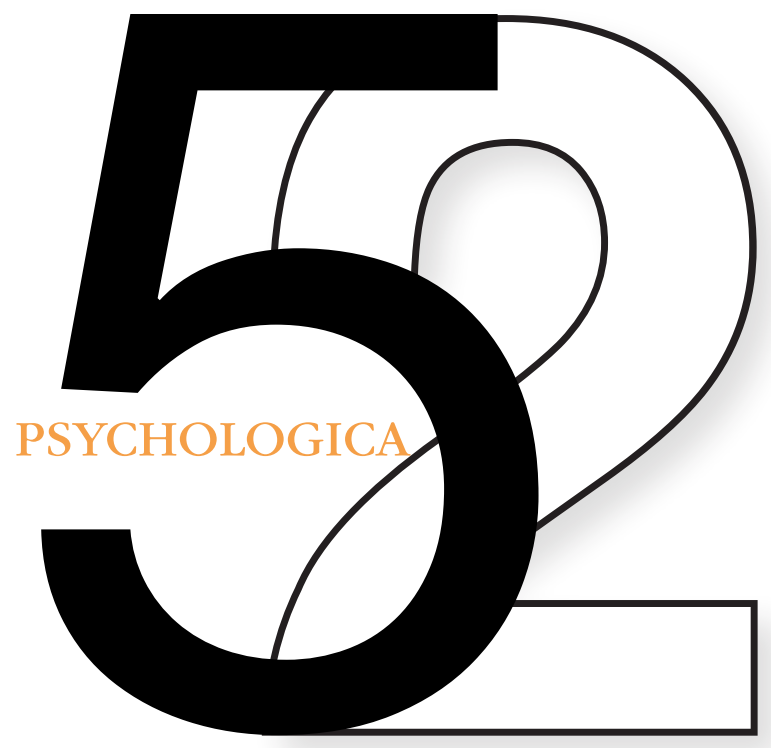

VOLUME II

IMPRENSA DA UNIVERSIDADE DE COIMBRA

FACULDADE DE PSICOLOGIA E DE CIÊNCIAS DA EDUCAÇÃo DA UNIVERSIDADE DE COIMBRA 


\section{Transição e ajustamento de reclusos ao estabeleci- mento prisional}

Filipa Alexandra Grilo Novais', Joaquim Armando Ferreira², Eduardo Ribeiro dos Santos³

O sistema prisional e os processos inerentes ao mesmo ainda são um tema pouco explorado e abordado no nosso país, começam-se a dar os primeiros passos na compreensão não só do sistema punidor e ressocializador em si, como também procura compreender as dinâmicas envolvidas: o recluso, adaptação deste, a delinquência, a personalidade anti-social, o crime, a punição.

A presente investigação, procurou através de uma abordagem qualitativa compreender as percepções e opiniões de um conjunto de reclusos quanto à sua experiência de vida na transição de um meio livre para um meio totalitário, e o ajustamento diferenciado que cada recluso fez. Através de um guião de entrevista semi-estruturado procuramos analisar seis grandes dimensões (estado de saúde, situação familiar, suporte social intra-prisão, prisão actual, transição e ajustamento, projectos futuros e resiliência) e as vivências de cada recluso nestas dimensões.

Verificamos que cada caso é um caso, e para interpretar a opinião de cada recluso temos que ter em consideração vários factores, entre eles o factor familiar, factor institucional, as características individuais de cada um, a história de desenvolvimento, o tipo de crime, a percepção que cada recluso tem do mesmo, o cumprimento de pena. Só depois de uma análise e uma abordagem total ao "Self" é que poderemos tentar compreender o indivíduo no seu todo e a sua adaptação à prisão.

PALAVRAS-CHAVE: Prisão, Ajustamento, Transição, Reclusos.

\section{Introdução}

Ainda que o sistema prisional seja uma realidade para muitos de nós ainda noutra dimensão, a verdade é que ela existe, havendo cada vez mais investigadores a interessarem-se pelo seu estudo (Sykes, 1958, Goffman, 1961, 1986 cit. in Gonçal-

\footnotetext{
1 Psicóloga. Mestrado Integrado em Psicologia da Educação, Desenvolvimento e Aconselhamento, FPCEUC - Filipa_Grilo_Novais@hotmail.com

2 Faculdade de Psicologia e de Ciências da Educação da Universidade de Coimbra - jferreira@fpce.uc.pt 3 Faculdade de Psicologia e de Ciências da Educação da Universidade de Coimbra - eduardosantos@fpce.uc.pt
} 
ves, 2008). A maior parte das investigações têm-se centrado na compreensão de como cada individuo lida com o cumprimento da sua sentença (Gonçalves, 2008).

Este cumprimento de pena ou sentença e o modo como lidam com esse cumprimento é uma questão variável de individuo para individuo, ao qual também se terá de ter em conta vários contornos importantes, como a natureza do crime, qual o estrato social de onde é oriundo (mais ou menos desfavorecido), o facto de estarem presos por imposição de terceiros - sejam eles o Tribunal ou a própria Sociedade). O facto de saberem que mais cedo ou mais tarde também serão restituídos à liberdade e à sociedade condiciona também a forma como eles encaram a sua adaptação à prisão e tal facto terá repercussões nas medidas flexibilizadoras da pena e nos próprios planos de tratamento.

Alguns estudos surgiram na década de oitenta alusivos aos processos adaptativos dos reclusos, Johnson \& Toch, 1982; Carbonell, Moohead \& Megargee, 1984; Hanson, Moss, Hosford \& Johnson, etc. (cit. in Gonçalves, 2008). Surge também na literatura algumas revisões teóricas e instrumentos criados especificamente para avaliar qualitativa e quantitativamente o modo como cada recluso se ajusta ao cumprimento da sua pena (Brodsky \& Smitherman, 1983; Megargee \& Carbonell, 1985 cit. in Gonçalves, 2008).

Todos estes estudos culminaram na conclusão de que a ocorrência de distúrbios emocionais e os problemas adaptativos que surgem são geralmente no início da pena. À medida que os reclusos se vão habituando ao encarceramento e ao cumprimento das normas estes distúrbios emocionais e problemas adaptativos têm tendência a dissipar-se por si.

\section{A Prisão, a família e a prevenção da toxicodependência: factores de socialização e ressocialização}

A Prisão encarada como elemento socializador e ressocializador entre o meio livre e meio fechada alberga em si muitos factores que contribuem para ao modo como cada recluso percepciona esta situação de transição e consequentemente o seu ajustamento quer à instituição, quer ao modo como irá encarar o seu cumprimento de pena e tratamento penitenciário.

Um desses factores é o factor familiar: o modo como a família tem um papel crucial no desenvolvimento da criança e a influência, neste caso, se há antecedentes criminais e a forma como uma família pode ou não forjar um potencial criminoso (McCord, 2002). Segundo este autor, o crime tende a propagar-se nas famílias: as famílias influenciam o desenvolvimento dos seus descendentes 
através da sua situação social e física. O próprio meio físico, a educação dos pais e o meio socioeconómico tem consequências de grande importância nas crianças, acontecendo a mesma situação no meio onde vivem. Bullock (2002) aborda também este tópico ao nível das influências familiares, a dinâmica familiar e as relações entre irmãos que podem contribuir ou não para o desenvolvimento do comportamento anti-social e consequentemente delituoso: assim nas famílias em que a conduta anti-social e o abuso de drogas são comuns, os irmãos são mais facilmente expostos a meios em que a conduta criminosa seja uma constante.

Born (2003) categoriza também os factores que influenciam a delinquência: estabilidade da residência, qualidade das habitações, realçando a situação económica da família, a composição da família - destacando as famílias desfeitas por morte, divórcio, separação; as características comportamentais também são consideradas por este autor, assim como a qualidade da vida familiar e as relações vinculativas dos seus membros.

A família, como vimos anteriormente, tem assim um papel importante no percurso desenvolvimental de todos. Além de poderem influenciar a "entrada no mundo criminógeno", podem também contribuir e influenciar o modo como cada recluso irá encarar o encarceramento, sobretudo a nível de suporte e apoio emocional durante este período (Comfort, 2007). Segundo Clemmer (1940) a manutenção de contactos sociais e familiares com o exterior durante o cumprimento da pena constitui outro condicionante do grau de adaptação à prisão. Assim, segundo este autor, a falta de contacto com os parentes e amigos contribui para um distanciamento quer em relação ao sistema institucional da prisão, quer em relação às normas e valores da sociedade que este representa.

Outro dos factores que influencia e condiciona o ajustamento e adaptação ao estabelecimento prisional é a própria prevenção e/ou intervenção que se fazem junto dos reclusos toxicodependentes que dão entrada nas prisões em número significativo.

Assim, a prevenção (Soares de Melo, 2002) é a chamada intervenção realizada no âmbito da toxicodependência que visa evitar que aconteça algo negativo. "É geralmente uma estratégia recomendada com base no pressuposto de que o estado de um sistema - individual, familiar, comunitário - anteriormente a um problema é mais harmonioso e como tal, objecto de um menor esforço técnico par preservar a sua funcionalidade". A prevenção da toxicodependência realizada nos estabelecimentos prisionais visa aproveitar o tempo de reclusão para promover a aquisição de estilos de vida saudáveis, implementando programas de prevenção da doença e de promoção da saúde, entre os quais os de redução de riscos e de minimização de danos. Santos Silva (2001) defende estas mesmas ideias usando 
o tratamento como instrumento de reinserção. Para este tratamento obter os resultados alcançados dever-se-á fazer um estudo e uma aposta nas análises das redes sociais que irão ter um papel fundamental na futura reinserção do recluso toxicodependente (Caplan, 1974, cit in Santos Silva, 2001) define redes sociais como sendo "o emaranhado de vínculos sociais que desempenham um papel importante na manutenção da integridade física e psicológica da pessoa".

\section{Contributos da Psicologia na definição de adaptação}

As primeiras definições de definição surgiram no campo do evolucionismo com Lamarck e Darwin que já no seu tempo defendiam que a adaptação surgia em consequência da sobrevivência, isto é, os mais fortes seriam os que numa luta estariam mais aptos e portanto, melhor adaptados. No campo da biologia foram muitos os que usaram o termo de "bem adaptados e mal adaptados" (Selye; 1956, cit. in Gonçalves, 2008) elabora a teoria do Síndrome Geral de Adaptação a qual defende que no organismo acontecem um conjunto de alterações psicofisiológicas sempre que o organismo se sente sob ameaça de agentes nocivos.

Nas ciências sociais o primeiro paradigma assenta na ideia que o homem enquanto ser bio-psico-social e o seu comportamento é fruto das interacções que faz. (Gonçalves, 2000). À medida que vai interagindo com os restantes indivíduos da sua espécie, vai condicionando e moldando a sua personalidade às situações, ao meio envolvente. É aqui que aparece o conceito de "adaptação". Segundo Sillamy, (1980, cit in Gonçalves, 2008) defende que este conceito (adaptação) surge em função da personalidade, isto é "à forma como, num momento dado e em função de um determinado meio, ajusta o seu comportamento à situação tendo a presente flexibilidade das estruturas e esquemas mentais.

Vários ramos da psicologia procuram explicar este conceito e este termo tão fundamental para este estudo. A Psicologia Educacional explica este conceito ligado ao desenvolvimento, sobretudo a nível da adaptação escolar que cada criança faz ou tem, fazendo a distinção entre adaptados e os inadaptados, sendo fundamental que a despistagem e o diagnóstico surjam precocemente para uma intervenção eficaz. Já a Psicologia Clínica, Psicoterapia e Psicopatologia, aborda a adaptação no "sentido em que se procura o equilíbrio emocional do sujeito que, por força de um distúrbio de características recorrentes (...) eventualmente precipitado por um acontecimento de vida, foi momentaneamente abalado" (Gonçalves, 2000). Esta procura conciliar a compreensão que se faz à personalidade do indivíduo e as suas perturbações para posteriormente procurar estratégias de tratamento aos eventuais problemas de adaptação que surjam. 
A Psicologia Social: é onde o termo de adaptação surge com maior força, uma vez que é nesta área onde surgem variáveis e aspectos psicossociais (personalidade, atitudes, identificação com determinados grupos, papeis e estatutos, etc), assim como aspectos relacionados com hábitos adaptativos - quando nos adaptamos a um tipo particular de circunstâncias ou situações que ocorrem. Insiste-se nesta área no termo da adaptação enquanto processo, na medida em que nos moldamos consoante as situações, circunstâncias e acções (Gonçalves, 2000).

\section{Adaptação como um Processo}

O homem como sistema bio-psico-sociológico integra em si o processo de adaptação, colocando em constante confrontação a sua personalidade com o meio físico e social no qual se encontra integrado e interage. Neste processo há ainda variáveis importantes a ter em conta num chamado bom ajustamento social: ambiente familiar, dificuldades escolares, temperamento impulsivo, etc.

Adaptar-se à prisão consiste assim, em conciliar a personalidade e feitio de cada recluso e o embate causado pela instituição fechada como é a prisão. Uma adaptação bem sucedida é então caracterizada como sendo o resultado do processo equilibrador em que o recluso tenta assimilar as regras institucionais e fechadas do sistema prisional aos seus esquemas comportamentais, sem no entanto, perder a sua individualidade. Agir como um objecto/actor dentro do próprio sistema (Gonçalves, 2008).

O papel da prisão surge aqui com dupla funcionalidade, como punidora e ressocializadora. Punidora na medida em que é considerada como principal forma de castigar o indivíduo, para que este sinta que os seus comportamentos interferiram com a sociedade ou alguém em particular e que por tal, deverá cumprir uma penalização proporcional ao delito cometido (Foucault, 1975; Gonçalves, 2007). Ressocializadora no sentido que tenta transmitir e ensinar ao individuo delinquente novos estilos comportamentais, para que no futuro não volte a enveredar por caminhos delituosos. Pais (1991) afirma que as variáveis preditoras de um bom ajustamento e adaptação à prisão passa por factores de natureza pessoal: personalidade, frequência e qualidade das relações que o recluso mantém no exterior da prisão a forma como estas relações influenciariam o modo de encarar o encarceramento e a privação da liberdade.

Assim neste processo de adaptação e ajustamento à prisão para que se defina como sendo "uma boa adaptação" deve começar por incorporar e equilibrar em si os elementos da instituição totalitária (Goffman, 1986) e acomodar os seus esquemas comportamentais individuais. A ressocialização e o bom ajustamento 
só será completo se o suporte exterior for protector e influenciar positivamente a adopção de novos estilos comportamentais.

Seguindo esta ideia, a adopção de novos estilos comportamentais passa também pela capacidade de resiliência que cada indivíduo vai adquirindo no tempo do encarceramento. Rutter (1990) foi um dos autores que mais aprofundou este conceito de resiliência, usando-o para classificar a capacidade do indivíduo para uma adaptação bem sucedida na presença de uma situação de adversidade, envolvendo múltiplos riscos e ameaças internas e externas ou ainda a capacidade de recuperação na sequência de uma experiência traumática prolongada. Este conceito, porém, é relativo pois nem todas as pessoas são resilientes em todos os momentos adversos das suas vidas, varia consoante as capacidades individuais e do próprio meio. Com os reclusos passa-se a mesma coisa, uma vez que perante situações adversas nas suas vidas é preciso analisar a sua capacidade de ultrapassar os seus problemas. Freitas et al (1998) fazem alusão a este conceito na medida em que o meio onde a pessoa cresce e os valores socioeconómicos pela qual a sociedade se rege terão repercussões no modo como cada indivíduo assimilará as suas capacidades individuais de lidar e enfrentar situações adversas. Deste modo, para compreender o recluso é também necessário entende-lo como um todo.

\section{Estudos de adaptação à prisão}

Vários estudos realizados nos EUA têm-se debruçado por esta temática: a compreensão da adaptação dos reclusos nos estabelecimentos prisionais. Sobretudo na década de 80 vários autores incidiram o seu interesse na problemática na forma como cada indivíduo lida com o cumprimento da sua sentença que no presente irá influenciar o seu futuro (quer no interior do estabelecimento, quer no exterior, aquando da sua libertação). Johnson e Toch (1982) abordam os processos adaptativos às prisões, existindo também várias investigações que incidem sobretudo na utilização das provas psicométricas e através das classificações tipológicas (cf. Carbonall, Moorhead \& Hayman, 1984; Carey, Garske \& Ginsberg, 1986; Hanson, Moss, Hosford \& Johnson, 1983; Wright, 1988).

Cordillia (1983) por exemplo debruçou-se sobre os problemas de adaptação que os reclusos sentem, sobretudo a adaptação a eles próprios, sobretudo a nível de socialização com os restantes reclusos, a incapacidade de interagir uns com os outros. Goffman (1961/1980) estudou sobretudo os efeitos deletérios do encarceramento (problemas de despersonalização). Zamble e Porporino (1988) que através de um estudo longitudinal estudaram os problemas adaptativos e os processos de confronto, concluindo que a ocorrências de distúrbios emocionais e problemas de adaptação eram constantes no inicio do cumprimento da pena, 
mas que estes mesmos problemas iam atenuando à medida que se acostumavam à própria instituição (cf. Gonçalves, 2008).

Literatura mais recente aponta para uma realidade que se deve ter presente a reinserção social, através de políticas de prevenção da delinquência, apostando em medidas de socialização de modo a permitir a inclusão dos indivíduos na sociedade. Thompson (2000) refere o termo "bewilderment" (confusão) que se pode classificar como sendo o sentimento que muitos dos reclusos sentem quando confrontados com a realidade exterior, sobretudo na área profissional. Feisher e Decker (2007) abordam a integração na sociedade de membros de exelementos de gang, focando a sua possível reincidência e ressalvando aspectos que se devem ter em conta a nivel comunitário. Visher e Travis (2003) focam-se nas dimensões que podem conduzir à adopção de comportamentos desviantes, sendo essas mesmas dimensões que podem afectar o processo de reintegração: características pessoais individuais, a situação e história familiar, o papel da comunidade como um factor de protecção e simultaneamente de risco.

Carter (2008) defende a reintegração e a inserção laboral dos ex-reclusos como forma preventiva da reincidência dos mesmos: "Inserir cada recluso num emprego estável e duradouro é um passo crucial para facilitar um regresso bem sucedido ao seu regresso na comunidade".

Giles et al (2004) focaram a sua investigação no papel da educação nas cadeias poderá ter na transição para o trabalho no exterior, tendo analisado primeiramente se os reclusos aderem ou não a estas iniciativas e a sensação optimista que os reclusos sentem acerca das suas escolhas nos termos da sua percepção futura de empregabilidade.

Vacca (2005) confirma a anterior ideia afirmando que os reclusos que assistem a programas educacionais enquanto estão encarcerados são menos propensos a voltar para a prisão após a sua libertação. Ramos (2006) incide também nesta ideia, sobretudo na especialização dos formadores penitenciários que têm que ter em conta a realidade da instituição e do que ela representa: “(...)consideração da prisão como um instrumento repressor e alienador e nas possibilidades de construir uma proposta educativa (e também social) que tenha um carácter crítico e transformador, podendo este actuar sobre as causas da exclusão".

Os primeiros estudos e investigações realizados em Portugal na área da Psicologia remontam a 1999, ilustrados na obra Psicopatia e Processos à Prisão (Gonçalves, 2008), facto que ilustra o problema base no nosso país: ausência de dados e estudos actuais, assim como representativos da população presidiária do nosso país (Grijó, 2008). Relativamente ao estudo da adaptação e ajustamento ao sistema prisional, este tema ainda não é muito abordado e analisado. Gonçalves (2000) 
realizou dois estudos até à data: o primeiro estudo de 1988-1990 e o segundo estudo mais recente (1995-1997).

O primeiro estudo (1988-1990) assentou nas questões:1) "Como definir a adaptação à prisão?", 2) "Como definir o que é uma boa adaptação à prisão?", 3) “Como definir o que é uma má adaptação à prisão?". Esta investigação assenta na ideia que a prisão é como um sistema, optaram assim por obter a visão da população vigilante tinha desta temática e confrontar as percepções dos guardas prisionais com a realidade existente (nomeadamente, uma comparação dos "perfis" existentes"). Foi colocada ainda a hipótese segundo a qual os guardas prisionais elegeriam os reclusos "bem-adaptados" como aqueles que não causassem quaisquer distúrbios e que tivessem um comportamento isento de reparos. O instrumento de recolha de dados escolhido foi uma entrevista semi-estruturada, a amostra recolhida foram 100 guardas do sexo masculino (cuja média de idades correspondia a 37.1 anos, e desvio-padrão 8,87). As conclusões deste primeiro estudo foram que segundo o ponto de vista do pessoal da vigilância um recluso bem adaptado é aquele que tem uma pena mais longa a cumprir, é bem comportado disciplinarmente, é reincidente e normalmente a cumprir uma pena por um crime de homicídio (cf.Gonçalves, 2008).

O segundo estudo foi realizado entre os anos 1995- 1997 e foi preparado de modo a permitir a análise dos resultados obtidos através do instrumento de medida do grau de adaptação "Prison Adjustment Index" (PAl; Wolfgang, 1961, cit in Gonçalves, 2008). Um dos objectivos deste estudo foi correlacionar os resultados obtidos com o PAI com o grau de psicopatia medido pela versão portuguesa da PCL-R de Hare (cf. Gonçalves, 2008). A amostra utilizada foi de 76 reclusos do sexo masculino a cumprir pena de prisão efectiva (média de idades de 34 anos e o desvio-padrão foi de 9.5). Os resultados e conclusões obtidos neste estudo foram a existência de diferenças significativas entre reclusos bem adaptados e reclusos mal-adaptados aos niveis da idade, estado civil, residência, habilitações académicas, crime, condenação, tempo de prisão cumprido, o facto de ser primário vs reincidente, assim como as punições sofridas e a ocupação que mantém dentro do E.P.

\section{Transições psicossociais: o modelo de Nancy Schlossberg}

Em vários contextos da nossa existência, várias transições e adaptações vão surgindo, várias mudanças a nível de papéis, rotinas, estatuto e relacionamentos interpessoais (Jorge, 2005). Estas mesmas mudanças são condicionadas por factores inerentes às características de cada indivíduo, sejam elas: características desenvolvimentais, à sua situação de vida, às estratégias a que recorrem para lidar com as adversidades e contextos que vão surgindo, assim como às estratégias 
de suporte com que podem contar em caso de necessidade. (Schlossberg, Waters \& Goodman, 1995).

A teoria da transição surgiu na década de 80, foi criada para explicar e compreender a transição em si, encarada como um processo e não como evento estático. (Gilmore et al, 1982). Deve assim ser compreendida como tal, assim como a sua diversidade e sua complexidade, tendo posteriormente se tornado uma ferramenta importante e indispensável no estudo da transição da vida adulta.

Simplificando a definição, transição passa pelo facto do individuo viver e percepcionar a transição como tal, mas sobretudo compreender a percepção da transição e de mudança (Jorge, 2005), sendo então encaradas como um "processo de continuidade e de mudança de relações através do tempo, processo sobre o qual os sujeitos buscam uma satisfação consigo mesmos e nas diversas situações" (Silva, 2007). Assim, o que realmente importa é que cada individuo, além de controlar os desafios e recursos, tente voltar estes mesmos seus recursos na procura do seu bem estar.

Schlossberg no seu modelo da transição incorpora as chamadas transições antecipadas (antecipaetd transition) - os eventos e situações aguaradas e programadas as quais o indivíduo anseia e conta que ocorram e que de certa forma pode antecipar e as transições não-antecipadas (unantecipated transition) - todos aqueles eventos e situações que não são esperadas pelo sujeito. Este modelo assume ainda que um individuo analisa e aprecia o significado que determinado evento tem para um possivel e imediato impacto no seu bem-estar, determinado ainda, quais os recursos pessoais e sociais intrínsecos ao próprio evento e quais as consequências oriundas. Existem ainda a transição que é devida a um acontecimento que é esperado mas que esse acontecimento não se chega a verificar, denomina-se de "non-event transition".

Além de termos que ter em consideração a compreensão, complexidade e diversidade de transições, há outros aspectos fundamentais neste processo: o contexto em que ocorre - pois o meio no qual individuo está inserido fica directa ou indirectamente afectado, e serem, igualmente determinantes na forma como o individuo lidará com a situação; o impacto ou grau de mudança - é um aspecto fundamental uma vez que dois indivíduos podem avaliar diversamente a mesma situação, os seus papéis de vida podem variar o impacto da transição em si. Cada transição acaba por ser única para cada indivíduo. O impacto das transições é dependente da sequência gradual ou repentina das mudanças e do entroncamento de outras transições. (Silva, 2007).

Quantas mais transições ocorrerem, recursos de coping e adaptação serão exigidos ao sujeito, ou seja, este terá que se adaptar às constantes mudanças existentes na sua vida. 
Nestes períodos de transição, um indivíduo assume diferentes papeis. Estes mesmos períodos requerem auto-avaliação e muitas vezes resultam em criar novas relações e novas atribuições de significado às mudanças (Leibowitz \& Schlossberg, 1982).

\section{Processo de transição}

Cada transição vai sofrendo alterações de acordo com o contexto em que ocorre, assim como as características pessoais do indivíduo.

Este processo de transição tem um tempo de acontecer, havendo um antes, um durante e um depois do acontecimento. Desde a preocupação da transição, até ao momento que o individuo assimila a transição como evidente.

Assim, o modelo de transição assume três fases de durabilidade: entrada, transição e saída (Bridges, 1980, cit. in Silva, 2007).

\begin{tabular}{l|l}
\hline Moving in & $\begin{array}{l}\text { Momento de abertura ou de começo de mudanças, em que se } \\
\text { dá inicio à exploração e ao contacto de novas características } \\
\text { da situação. }\end{array}$ \\
\hline Moving through & $\begin{array}{l}\text { É quando ocorre a activação e a manutenção dos sistemas } \\
\text { pessoas de apoio à transição. Onde o individuo procura a } \\
\text { ponderação, redefinição e avaliação necessárias ao sucesso } \\
\text { da transição. }\end{array}$ \\
\hline Moving out & $\begin{array}{l}\text { Pode-se considerar o momento de "pensar no que vem a } \\
\text { seguir", nomeadamente após as alterações verificadas nas } \\
\text { rotinas, papeis, percepções é necessário realizar um ajusta- } \\
\text { mento e integra-las no seu quotidiano. }\end{array}$ \\
\hline
\end{tabular}

A teoria de Schlossberg é conhecida e referida como sendo a Teoria dos 4 S's, uma vez que identifica os quatro factores que contribuem para o modo como cada um lida com a transição em si, a saber: a Situação (situation), Eu (self), Suporte (support), Estratégias (strategies).

Quanto à Situação (Situation), este refere-se ao acontecimento ou ausência do mesmo, assim como analisa as variáveis que caracterizam a transição: espaço, a duração, o controlo, fonte, mudança de papéis, experiência anterior, acontecimentos paralelos e avaliação que o indivíduo faz do acontecimento.

Relativamente aos factores inerentes ao recurso $\underline{\mathrm{Eu}}$ (Self), estes procuram compreender e identificar a situação pessoal do indivíduo, assim como os recursos psicológicos que dispõe (Silva, 2007): nível sócio-económico, o género, a idade, saúde, etnia e cultura, desenvolvimento do ego, optimismo e auto-eficácia, compromisso e valores. 
O terceiro S refere-se ao Suporte (Support) poderemos considerar o suporte social e a função desse suporte para o indivíduo, a forma como o percepciona e usa, engloba por um lado as redes de apoio provinda das várias redes sociais que existem (família, amigos, instituições, etc.) e por outro lado, a função que este apoio vai representar para o indivíduo.

Por fim, a última variável (quarto S) refere-se às Estratégias (Strategies) e estas referem-se ao conjunto de respostas adaptativas que o indivíduo usa para lidar com a transição, a fim de orientar a situação, o significado e o stress dela adjacente, sendo as mesmas: respostas de modificação da situação, respostas de controlo do significado do problema e respostas que ajudam na gestão do stress após o acontecimento transaccional.

\section{Transição e ajustamento na Prisão}

Atendendo ao facto que nesta situação especifica (sistema prisional), uma boa transição é o resultado de um processo equilibrador: em que o individuo tem que apreender o conjunto de regras inerentes à instituição e organização do próprio sistema prisional e conjugar essas regras e leis com o seu sistema biopsicosociológico. (Gonçalves, 2008), o qual integra em si vários aspectos relacionados com a sua personalidade assim como o modo como a sua personalidade evolui nos diversos contextos do meio e contextos sociais.

Esta transição e ajustamento às normas institucionais que em consonância com o traço de perfil de cada recluso é fundamental para o modo como irá lidar com o seu encarceramento e consequente cumprimento da pena. Não obstante, está também relacionada com o modo como encarará a sua vida fora dos muros da prisão. 'Bewilderment' (Simon, 1999, cit. in Thompson, 2000) é a expressão utilizada para tentar explicar o sentimento que os reclusos sentem quer na sua entrada, mas sobretudo na altura da sua libertação.

Pode-se definir como sendo um estado confuso e perplexo que muitos dos reclusos afirmam ter quando sentem aquando da sua saída. É causada por problemas de ajustamento e dissonância causada por diversas expectativas e experiências de vida no mundo exterior.

É neste ponto que a reinserção social deve manter-se atenta, procurar incentivar os reclusos a manter uma ocupação dentro do espaço intra-muros de modo a que estes além de se manterem ocupados comecem a sentir que estão a contribuir de forma eficiente para a sociedade. Thompson (2000) refere que no seu artigo 
que apesar do muito trabalho que façam dentro da prisão, este será vivido e experienciado de forma diferente para os reclusos.

Neste sentido, é importante que se avalie e analise o significado que cada recluso atribui à situação em si e ao contexto em que se encontram (sendo neste caso, um contexto intra-muros) e isto garante um maior controlo do sentido de motivação quer para o "manter-se ocupado", quer para o sentimento de cumprimento de pena.

A DGSP 4 tem procurado assim manter os reclusos ocupados: "O trabalho prisional, com finalidade educativa e produtiva e devidamente remunerado de acordo com a aptidão do recluso, tem sido desenvolvido dentro dos estabelecimentos prisionais no âmbito das infra-estruturas económicas existentes e através da articulação com entidades do sector público/privado, procurando-se assim diversificar as actividades ocupacionais/ laborais adequando-as, sempre que possivel, às características da população e à oferta de trabalho" (www.dgsp.mj.pt).

\section{Metodologia}

O presente estudo teve como objectivo principal a compreensão dos processos de transição para a prisão de reclusos primários e reincidentes. Assim, pretendemos analisar as vivências do ajustamento ao encarceramento, bem como sobre o processo de adaptação ao estabelecimento prisional.

As questões de investigação foram as seguintes:

De que forma o estado de saúde de cada recluso condiciona o seu ajustamento? Qual o grau de influência que o historial familiar do recluso tem para a sua adaptação a um regime fechado?

De que forma as estratégias adoptadas pelos reclusos a nível de suporte social permitem inferir uma boa adaptação?

Quais as diferenças nos reclusos na adaptação ao estabelecimento prisional, tendo em conta a sua situação jurídico-penal (reincidente vs primário)?

Quais as opiniões e percepções dos reclusos perante um bom ajustamento?

Qual o grau de resiliência dos reclusos perante a análise dos seus projectos de vida futuros?

4 Direcção Geral dos Serviços Prisionais 


\section{Amostra}

A amostra apresentada é constituída por 30 reclusos afectos a um Estabelecimento Prisional Regional, estando dois deles em situação preventiva, os restantes encontram-se já condenados e a cumprir pena.

Como era de nossa intenção averiguar e analisar as transições e ajustamentos efectuados por um conjunto de reclusos, procedeu-se à selecção aleatória de 30 reclusos, no entanto, esta recolha não deixa de ser intencional, uma vez que para o estudo foram requeridos algumas características dos elementos. A selecção da amostra não foi no seu total aleatória uma vez que surgiram algumas implicações na sua selecção, a saber: ocorrência de reclusos que se recusaram a participar na investigação (1 elemento) e eliminação de alguns reclusos devido ao seu historial de violência interpessoal (3 elementos).

Os 30 reclusos tinham idades compreendidas entre os 25 e os 54 anos, sendo 19 primários e 11 reincidentes. A escolaridade dos participantes era bastante baixa, tendo $401^{\circ} \mathrm{Ciclo}, 13 \circ 2^{\circ} \mathrm{Ciclo}, 12 \circ 3^{\circ} \mathrm{Ciclo} \mathrm{e} 1$ o ensino secundário.

\section{Instrumentos}

Para este tipo de estudo optou-se por usar uma análise qualitativa, cujo trabalho exige grande proximidade e interacção com o individuo e/ou grupo uma vez que estamos face a face com os mesmos. Este tipo de análise permite-nos compreender o modo como as pessoas pensam, sentem, interpretem e experimentam os acontecimentos em estudo (Ribeiro, 2007).

Existem várias técnicas de recolha de dados em investigação qualitativa, mas uma vez que o nosso estudo se prende com a opinião assente na experiência de vida de cada indivíduo na sua integração e ajustamento ao estabelecimento prisional, procurou-se ser o mais fidedigno à opinião de cada um. Usamos para isso, uma entrevista semi-estruturada (anexo II). Optámos por esta técnica uma vez que é um bom método para se obterem informações que não são acessíveis mediante observação directa, assim como permite uma melhor captação das dimensões subjectivas implicadas em certos comportamentos, nomeadamente, saber quais são as representações que os reclusos possuíam em relação à prisão, ao próprio sistema judicial, assim como apoio familiar e futura reinserção e investimentos sociais.

Como esta entrevista incide sobre a opinião de cada recluso a um conjunto de factores inerentes ao sistema prisional, elaboramos um conjunto de questões subdivididas em dimensões assentes nos temas que quisemos explorar. As dimensões foram as seguintes: elementos sociodemográficos; situação jurídico- 
penal; estado de saúde; situação e apoio familiar; suporte social intra-prisional; prisão actual; transição e ajustamento ao estabelecimento prisional; projectos futuros/futura reinserção.

O total de questões aplicadas (58) e entrevistas realizadas (30) permitiram e tiveram por objectivo uma abordagem detalhada na recolha de relatos, opiniões e percepções por parte dos reclusos com base na sua experiência de vida num sistema fechado como é o sistema prisional.

A entrevista realizada assentava em questões abertas para os reclusos-participantes, permitindo-Ihes deste modo que respondessem à "sua maneira" (usando o seu vocabulário) assim como permitia que descrevessem pormenores ou tecessem comentários sobre as várias dimensões discutidas. Todas as suas respostas e informações obtidas foram registadas e alvo de análise por parte do investigador. Ponderamos o uso de gravador áudio na sessão, mas tal não foi possível por duas razões: 1) estas questões têm que ser autorizadas pela DGSP, um processo em si demoroso; 2) receámos que o uso do gravador intimidasse os reclusos e estes se sentissem inibidos nas suas respostas, criando assim o "corte" de informação que viria acontecer, o que enviesaria todo o processo de investigação.

Posteriormente à recolha propriamente dita, procedeu-se à primeira fase de análise de conteúdo, através de compactação das entrevistas, assim como através de unidades de registo para cada uma - tal acto permitirá futuramente a consulta e análise, para discussão dos resultados.

\section{Procedimentos}

A presente investigação decorreu num Estabelecimento Prisional Regional. As entrevistas foram realizadas consoante a disponibilidade de cada recluso-participante. Antes de qualquer procedimento, o recluso era chamado e convidado a participar no projecto de investigação, onde era explicado qual o propósito da investigação, quais os objectivos estabelecidos, assegurando que as condições éticas seriam todas consideradas.

De seguida, era entregue ao recluso-participante uma declaração de consentimento informado, na qual estaria explicito tudo o que havia sido dito anteriormente - ressalvando uma vez mais que o conteúdo da entrevista seria usado única e exclusivamente para a investigação em curso, seria um contributo anónimo no qual opiniões e pareceres pessoais seriam fundamentais para o objecto em estudo.

Uma vez assinada a declaração de consentimento informado, procedia-se à entrevista propriamente dita, esta entrevista semi-directiva foi construída de modo 
a abranger as dimensões mais pertinentes para o nosso estudo. Para analisar estas dimensões procedeu-se à realização de um guião de entrevista, dividido num agrupamento temático, ou seja, agrupamos as questões mais pertinentes em grupos de análise para facilitar quer a sua aplicação, quer posteriormente a sua análise. Procuramos seguir uma simplicidade na formulação, permitindo

deste modo, suscitar a reflexão pessoal, para evitar desta forma a tentação das respostas dicotómicas (Jorge, 2005). Foi realizada a pensar no sistema fechado como é a o sistema prisional, assim como as opiniões, sentimentos e crenças de cada recluso à sua situação específica.

Eram realizadas sensivelmente três a quatro entrevistas por semana aos reclusos (este número variava consoante a disponibilidade de cada recluso), tendo sido realizadas na totalidade 30 entrevistas, estas decorreram dentro da normalidade, tendo cada recluso demorado sensivelmente entre 30 a 45 minutos a responder às questões.

\section{Resultados}

Após uma breve leitura às entrevistas realizadas, procedemos à análise de conteúdo. Então desta emergiram seis dimensões principais: Estado de Saúde, Situação Familiar, Suporte Social, Prisão Actual, Transição e Ajustamento ao Estabelecimento Prisional (E P) e Projectos Futuros.

Assim, para cada questão pertinente em cada dimensão analisada, foi construído um quadro no qual contem a dimensão, subdimensão, categoria e respectivas frequências. Para permitir uma simplificação e compreensão da análise, procedemos à ilustração das Subimensões e categorias com algumas transcrições das entrevistas.

Na primeira dimensão - Estado de Saúde, as questões debruçaram-se essencialmente nos seguintes aspectos: hábitos de consumo; Contexto psicossocial relativo ao consumo de drogas; consume de outro tipo de substâncias; abstinência, recaídas e motivação para o tratamento. 
Tabela 2. Primeira Dimensão: Estado de Saúde

\begin{tabular}{|c|c|c|c|}
\hline Dimensão & Subdimensão & Categoria & Frequências \\
\hline \multirow{18}{*}{$\begin{array}{l}\text { Estado de } \\
\text { Saúde }\end{array}$} & \multirow{3}{*}{ Hábitos de consumo de drogas } & \begin{tabular}{|l|} 
Presente \\
\end{tabular} & 22 \\
\hline & & Ausente & 8 \\
\hline & & Consumo parcial & $\mathrm{O}$ \\
\hline & TOTAL & & 30 \\
\hline & \multirow{3}{*}{ Contexto } & Grupo de pares & 14 \\
\hline & & \begin{tabular}{|l|} 
Curiosidade \\
\end{tabular} & 7 \\
\hline & & \begin{tabular}{|l} 
Familia \\
\end{tabular} & 1 \\
\hline & TOTAL & & 22 \\
\hline & \multirow{4}{*}{$\begin{array}{l}\text { Consumo de outras substân- } \\
\text { cias }\end{array}$} & Álcool & 5 \\
\hline & & \begin{tabular}{|l} 
Tabaco \\
\end{tabular} & 18 \\
\hline & & Medicação & 5 \\
\hline & & Não consome nada & 2 \\
\hline & TOTAL & & 30 \\
\hline & \multirow{4}{*}{ Tratamentos } & Realiza(dos) & 12 \\
\hline & & Desistidos & 5 \\
\hline & & Concluídos & 5 \\
\hline & & Nunca realizou & 8 \\
\hline & TOTAL & & 30 \\
\hline
\end{tabular}

Na primeira dimensão: Estado de Sáude verifica-se que a maioria dos sujeitos apresenta problemas relacionados com o consumo de estupefacientes (22 reclusos revelam e evidenciam hábitos de consumo antes da sua entrada no EP contrapondo com os 8 reclusos que afirmam que nunca tiveram consumos até à data), podemos confrontar esta situação através da confrontação das afirmações de três reclusos (dois consumidores e outro não-consumidor): "Heroína e cocaína desde muito jovem" (E5); "Agora só tabaco, mas consumia heroína e cocaína" (E7) comparativamente a "Nunca consumi" (E30).

Relativamente ao contexto onde estes consumos tiveram inicio, desses 22 reclusos que afirmaram anteriormente que tinham tido contacto directo com os consumos, 14 reclusos afirmaram que esses consumos ocorrem em contexto de grupo de pares, 7 afirmam que foi em contexto da curiosidade típica da idade e apenas 1 afirmou que tinha sido em contexto familiar, influenciado por um ou mais elementos: "Justifica-se com a história de desenvolvimento e a curiosidade típica da idade, (...) existência da mesma problemática de consumo e dependência de estupefacientes com os irmãos mais velhos." (E1). Verificamos também o contexto do grupo de pares "Comecei a consumir aos 20 anos com os amigos" (E17).

Quanto aos consumos de outras substâncias, encontramos nesta amostra de 30 sujeitos, que todos os sujeitos consomem outras substâncias: 5 afirmam consumos de álcool, frequentes ou esporádicos: "Refere algum consumo abusivo de álcool propiciado pela sua profissão (empresário da noite)" (E10); 18 desses 
reclusos assumem o consumo de tabaco com alguma regularidade: "Comecei a fumar tabaco aos 19 anos e ainda mantenho." (E7); e 5 afirmam que consomem medicação devido à sua condição de saúde: "Álcool, para substituir as drogas. E medicamentos para me controlarem os pensamentos" (E23).

Quando à ultima subdimensão: Tratamentos, verificamos que grande número de reclusos já efectuou ou ainda se encontra a realizar tratamento (12): "Estou a fazer tratamento no CAT e aqui dentro da prisão, com o médico" (E9). Verificamos também que existe um número ainda bastante significativo de reclusos que nunca realizaram tratamento: "Nunca realizou qualquer tipo de tratamento para os consumos, afirmando que o seu consumo de haxixe era muito esporádico" (E16). Conferimos também pela análise da tabela e das entrevistas que também existem reclusos que iniciaram o tratamento, mas que a dado momento acabaram por desistir do mesmo (5 reclusos da nossa amostra afirmaram-no): "Estive no Projecto Homem um ano, mas não me valeu de muito, porque voltei a recair." (E27); "Fiz alguns tratamentos no CAT mas não deram resultado... Aqui também desisti do programa da metadona" (E7); Desta nossa amostra de 30 reclusos, conferimos também que 5 reclusos iniciaram e estão prestes a concluir com êxito algum tratamento: "O único tratamento que faz refere que é para os problemas renais, estando a ser seguido com regularidade pelo médico do E.P." (E8); "Agora não estou em nenhum tratamento, mas já fiz alguns no CAT" (E20).

Relativamente à segunda dimensão principal: Situação Familiar e Suporte, as questões foram as seguintes: como considera ter sido o papel da sua família ao longo da sua vida? Como era a sua relação com os seus pais? e irmãos? E com outras figuras relevantes (avós, tios, primos...)? Actualmente ainda mantém o mesmo tipo de relação? A quem recorre quando precisa de ajuda?

Tabela 3. Segunda Dimensão: Situação Familiar e Suporte

\begin{tabular}{|c|c|c|c|}
\hline Dimensão & Subdimensão & Categoria & Frequências \\
\hline \multirow{14}{*}{$\begin{array}{l}\text { Situação Fa- } \\
\text { miliar } \\
\text { e Suporte }\end{array}$} & \multirow{3}{*}{$\begin{array}{l}\text { Relacionamento com a } \\
\text { família }\end{array}$} & Bom & 20 \\
\hline & & Razoável & 8 \\
\hline & & Precário & 2 \\
\hline & TOTAL & & 30 \\
\hline & \multirow{3}{*}{$\begin{array}{l}\text { Papel da Família no seu } \\
\text { desenvolvimento }\end{array}$} & Importante & 16 \\
\hline & & Mediano & 10 \\
\hline & & Pouco Importante & 4 \\
\hline & TOTAL & & 30 \\
\hline & \multirow{5}{*}{ Figura de suporte e apoio } & Pais & 11 \\
\hline & & Irmãos & 9 \\
\hline & & Cônjuge & 5 \\
\hline & & $\begin{array}{l}\text { Outro(s) } \\
\text { Familiar(es) }\end{array}$ & 1 \\
\hline & & Não se verifica & 4 \\
\hline & TOTAL & & 30 \\
\hline
\end{tabular}


Analisado o estado de saúde (como se verifica na dimensão anterior), procuramos averiguar e compreender a situação familiar de cada recluso, analisar a existência de vínculos afectivos aos elementos familiares, o papel de família no decurso desenvolvimental do recluso e perceber qual é a figura de suporte e apoio de cada recluso, sobretudo durante este período da reclusão. Assim, na primeira subdimensão avaliada nesta dimensão: Relacionamento com a Família, podemos concluir que da nossa amostra de 30 sujeitos, 20 sujeitos afirmam que mantêm bom relacionamento familiar pautado por laços de proximidade e afectividade entre grande maioria dos elementos. Podemos verificar isso pela ilustração das seguintes afirmações: "Cresceu com os pais e com os irmãos e declara que mantinham bom relacionamento interpessoal. Afirma que actualmente ainda mantém fortes laços familiares e o seu relacionamento com os familiares é emocionalmente estável e equilibrado" (E2); Boa relação, incluindo os irmãos" (E4); "Bom relacionamento, até com a família do meu pai" (E12); Temos também registo que 8 reclusos afirmaram que o seu relacionamento é razoável com as respectivas famílias: "É o mais novo da fratria razão pelo qual afirma que o relacionamento com o agregado familiar não fosse dos melhores ("sou o mais novo, os meus irmãos mais velhos tem 20 anos de diferença, logo eles não tem tanta paciência e compreensão pelo meu caso"). Actualmente refere que tem um relacionamento razoável com os mesmos" (E9); Era bom, mas havia situações de agressão física lá em casa... Actualmente já passaram essas chatices, agora damo-nos bem" (E16). Ainda na mesma dimensão, surgem-nos o registo de 2 reclusos que afirmam que o relacionamento com a família é precário: Manteve sempre bom relacionamento com os pais até iniciar os consumos, a partir daí começou a surgir uma deterioração e um afastamento progressivo. Actualmente não mantém qualquer tipo de contacto com os progenitores, considera que o estejam a "castigar" para ver se "ganha juízo" (E5); "Perdi contacto com alguns, desde que comecei a meter-me nas drogas. Não tenho falado com muitos..." (E21)

Na segunda subdimensão estudada e analisada: Papel da Família, procurou-se averiguar qual é o papel que cada recluso atribuiu à sua família durante o seu crescimento e ainda atribui nos dias de hoje, sobretudo durante esta fase de transição e ajustamento a um sistema totalitário (Goffman,1986). Verifica-se que 16 reclusos consideram que a família teve um papel importante no seu percurso vivencial: "Teve sempre um papel importante." (E24); Surge-nos também em número significativo reclusos que apontam que o papel da família foi mediano (10 reclusos): "Foi bom, mas podia ter sido melhor, com mais apoio, sobretudo por parte da família paterna." (E26). Apenas 2 reclusos desvalorizam o papel que a família teve durante o seu crescimento, classificando-o de precário: “Fraco, podia ter sido muito melhor..." (E17). 
Nesta última subdimensão: Figura de Apoio e Suporte quisemos entender qual era a figura de apoio que por norma os reclusos tinham dentro da sua família. Deste modo, 11 reclusos apontaram como principais figuras os pais: "Aponta como principal figura de apoio a sua progenitora, com quem mantém laços de grande proximidade e afectividade, sendo a mesma que o acolhe quando está no exterior" (E8); 9 reclusos anunciaram os irmãos como principais figuras de suporte: "Os irmãos, apoiamo-nos uns aos outros!" (E6); 5 reclusos apontam a cônjuge/companheira como figura de suporte: "Conto comigo mesmo e com a minha companheira" (E29). Os restantes reclusos (5) têm noutros familiares as suas figuras de suporte e apoio (1) ou então pelo contrário, não se verifica o apoio por parte dos familiares.

Quanto à terceira dimensão: Suporte Social Intra-Prisão, as questões da entrevista que consideramos pertinentes para esta análise foram as seguintes: Como são os seus relacionamentos aqui na prisão? Com os restantes companheiros/reclusos? E com os guardas prisionais? E com a própria administração? Se precisar de ajuda, pode contar com alguém cá dentro? Se sim, quem?

Tabela 4. Terceira Dimensão: Suporte Social Intra-Prisão

\begin{tabular}{|c|c|c|c|}
\hline Dimensão & Subdimensão & Categoria & Frequência \\
\hline \multirow{6}{*}{$\begin{array}{l}\text { Suporte Social } \\
\text { Intra-Prisão }\end{array}$} & \multirow{2}{*}{ Relacionamentos intra-prisão } & $\begin{array}{l}\text { Bons com todos os } \\
\text { elementos }\end{array}$ & 21 \\
\hline & & Só com alguns & 9 \\
\hline & \begin{tabular}{|l|} 
TOTAL \\
\end{tabular} & \multicolumn{2}{|l|}{30} \\
\hline & \multirow{3}{*}{ Suporte Social intra-prisão } & Presente & 17 \\
\hline & & \begin{tabular}{|l|} 
Parcial \\
\end{tabular} & 8 \\
\hline & & Ausente & 5 \\
\hline & TOTAL & 30 & \\
\hline
\end{tabular}

Nesta terceira dimensão: Suporte Social Intra-Prisão, quisemos averiguar o tipo de suporte que cada recluso da nossa amostra tem intra-muros (analisar a qualidade de relacionamentos entre os reclusos e os vários elementos do sistema prisional) e a existência ou ausência de suporte social intra-prisão.

Verificamos assim que 21 reclusos declaram bom relacionamento com todos os elementos: "Dou-me bem com toda a gente, não tenho razões de queixa de ninguém!" (E17) comparativamente a 9 reclusos que afirmam bons relacionamentos apenas com alguns elementos: "Dou-me razoavelmente, há reclusos com quem não me dou, mas com os guardas e administração dou!” (E14).

Quando ao Suporte Social Intra-Prisão, verificamos que este mesmo suporte se verifica por 17 reclusos, os quais afirmam que têm sempre alguém com quem contar caso seja necessário: "Com os chefes e Direcção" (E4); 8 reclusos afirmam que têm parcial suporte social: "Caso necessite de ajuda dentro do E.P. diz que 
pode contar com alguns reclusos e o pessoal da vigilância." (E11); e apenas 5 reclusos afirmam que não contam com ninguém, afirmando ausência de suporte social intra-prisão: "Quando questionado se sente respeitado enquanto pessoa, responde que "mais ou menos, tem dias", afirmando que caso necessite de ajuda é com ele próprio que conta" (E20).

Na quarta dimensão: Prisão Actual - as questões mais pertinentes da entrevista para analisar esta dimensão foram as seguintes: É a primeira vez que está preso? Se sim, há quanto tempo está preso? Em que circunstâncias ocorreu o crime? (Grupo de amigos, família, drogas...) Qual foi a sua reacção no $1^{\circ}$ dia em que entrou numa prisão?

Tabela 5. Quarta Dimensão: Prisão Actual

\begin{tabular}{|c|c|c|c|}
\hline Dimensão & Subdimensão & Categoria & Frequência \\
\hline & Dric̃̃ 1 ctu & Primário & 16 \\
\hline & PIISaU Actual & Reincidente & 14 \\
\hline & TOTAL & 30 & \\
\hline & & - Menos de 1 Ano & 10 \\
\hline & $\begin{array}{l}\text { Permanência no } \\
\text { FP }\end{array}$ & - Menos de 3 Anos & 12 \\
\hline & & + Mais de 3 anos & 8 \\
\hline & TOTAL & 30 & \\
\hline & & Grupo de pares & 5 \\
\hline & Circunstâncias em & $\begin{array}{l}\text { Contexto Familiar/Dific. } \\
\text { Económicas }\end{array}$ & 3 \\
\hline & que ocorreu o crime & Drogas & 15 \\
\hline & & Ambição & 2 \\
\hline & & Outra razão & 5 \\
\hline \multirow{6}{*}{ Prisão Actual } & TOTAL & \multicolumn{2}{|l|}{30} \\
\hline & \multirow{4}{*}{$\begin{array}{l}\text { Reacção no } 1^{\circ} \text { con- } \\
\text { tacto com a prisão }\end{array}$} & $\begin{array}{l}\text { Má, angústia, revolta, } \\
\text { tristeza }\end{array}$ & 18 \\
\hline & & "Normal" & 3 \\
\hline & & Reagiu bem & 5 \\
\hline & & Não se lembra & 4 \\
\hline & TOTAL & 30 & \\
\hline
\end{tabular}

Quanto à quarta dimensão: Prisão Actual, quisemos abordar e explorar a situação da prisão actual, mais concretamente aspectos jurídico-penais, crime, permanência dentro deste EP, circunstâncias em que ocorreu o crime e sobretudo analisar as reacções de cada recluso no primeiro contacto com a prisão e a privação da liberdade.

Desta forma, da nossa amostra de 30 reclusos (16) são primários, ou seja, é a primeira vez que se encontram em situação de cumprir pena num sistema totalitário e (14) reclusos são reincidentes, não sendo esta a primeira ou até mesmo a segunda vez que se encontram detidos. 
Quanto à permanência no EP, neste item quisemos saber há quanto tempo o recluso se encontra no estabelecimento prisional, não fazendo assim referência à pena - deste modo, quisemos verificar de que forma maior ou menor permanência dentro da prisão condiciona ou influencia os ajustamentos e adaptações dos reclusos. Assim, (10) reclusos estão detidos há menos de um ano, (12) reclusos estão detidos há mais de três anos e (8) reclusos é que se encontram detidos há mais de 3 anos.

Relativamente às circunstâncias em que o crime ocorreu, (5) reclusos referem-nos que ocorreu em contexto de influência do grupo de pares: "Fui abordado pelo NIC de Amarante e muito influenciado por maus amigos! E também pelo álcool..." (E6); 3 reclusos referem que o crime ocorreu em contexto familiar e/ou dificuldades económicas: "Foram as dificuldades económicas que atravessava na altura que explorava o café que tinha". ( E4); (15) reclusos referem que o crime ocorreu em contexto dos consumos de estupefacientes: "Foi por causa da droga, e também para arranjar dinheiro de forma fácil" (E9); "Fui apanhado a roubar por causa da droga, assim como fui levado pela ambição do dinheiro fácil p'ros consumos” (E14).

Apenas (1) recluso afirma que o crime ocorreu em contexto de ambição: "Fui levado pela ambição e obtenção de dinheiro fácil..."(E22); (5) reclusos referiram que os contextos em que ocorreram os crimes foram devido "a outras razões", nomeadamente condução ilegal: "Fui apanhado uma data de vezes a conduzir sem carta, mas foi sempre por causa do trabalho que tenho..." (E25); "Era apanhado sem carta...mas era apanhado sem carta quando estava a trabalhar...e deviam ter isso em consideração" (E26).

Quanto à quinta dimensão: Transição e Ajustamento ao Estabelecimento Prisional, as principais questões retiradas da entrevista foram: Em que é que encontrou mais dificuldades para se adaptar? Quais as principais alterações que considera terem ocorrido na sua maneira de estar/ser aquando e após este período de transição? Quais os principais factores (pessoais, sociais, académicos, institucionais) que acha que Ihe facilitaram a sua integração e ajustamento ao E.P.? Sente que de alguma forma está a ser preparado cá dentro para voltar a uma vida social "normal" quando sair em liberdade (reinserido na sociedade)? O que sugeria que fosse feito para preparar as pessoas que saem em liberdade? 
Tabela 6 - Quinta Dimensão: Transição e Ajustamento

\begin{tabular}{|c|c|c|c|}
\hline Dimensão & Subdimensão & Categoria & Frequência \\
\hline \multirow{23}{*}{$\begin{array}{l}\text { Transição e } \\
\text { Ajustamento }\end{array}$} & \multirow{2}{*}{ Dificuldades de integração } & Verificadas & 16 \\
\hline & & Ausentes & 14 \\
\hline & TOTAL & 30 & \\
\hline & \multirow{3}{*}{$\begin{array}{l}\text { Alterações na maneira de } \\
\text { estar/ser }\end{array}$} & Presentes & 14 \\
\hline & & Parciais & 9 \\
\hline & & Ausentes & 7 \\
\hline & TOTAL & 30 & \\
\hline & \multirow{4}{*}{$\begin{array}{l}\text { Factores de Integração/ } \\
\text { ajustamento ao E.P. }{ }^{1}\end{array}$} & Factores Pessoais & 14 \\
\hline & & Factores Sociais & 12 \\
\hline & & Factores Académicos & 19 \\
\hline & & Factores Institucionais & 6 \\
\hline & & Nenhum Factor & 1 \\
\hline & \begin{tabular}{|l|} 
TOTAL \\
\end{tabular} & 52 & \\
\hline & \multirow{2}{*}{$\begin{array}{l}\text { Sentimento de preparação } \\
\text { para futura reinserção }\end{array}$} & Sim & 19 \\
\hline & & Não & 11 \\
\hline & TOTAL & 30 & \\
\hline & \multirow{3}{*}{$\begin{array}{l}\text { Sugestões para futuros ex- } \\
\text { reclusos }\end{array}$} & +Saídas precárias & 3 \\
\hline & & +Apoio social & 6 \\
\hline & & $\begin{array}{l}\text { + Oportunidades de } \\
\text { trabalho }\end{array}$ & 11 \\
\hline & & + Ocupação laboral & 4 \\
\hline & & +Apoio Tratamentos & 4 \\
\hline & & Nada & 2 \\
\hline & TOTAL & 30 & \\
\hline
\end{tabular}

Esta quinta dimensão: Transição e Ajustamento ao Estabelecimento Prisional quisemos explorar a forma de como cada recluso na nossa amostra se adaptou ao $E P$, se se verificaram dificuldades de integração, se existiram alterações na maneira de ser aquando este período de transição, quais os factores facilitadores dessa mesma integração. Quisemos ainda analisar se os reclusos sentiam que estavam ser preparados para serem reinseridos novamente na sociedade e quais as sugestões que cada um apresentou para os reclusos que estivessem prestes a ser libertados.

Assim, (16) reclusos afirmaram sentir dificuldades de integração: "O que mais dificultou a sua integração e ajustamento foi o facto de estar longe da sua família, sobretudo da cônjuge e dos filhos e o tempo que tinha de estar na cela" (Entrevista caso 6); “À cela e ao espaço fechado" (E13); "Os primeiros dias repletos de regras e horários" (E19). Contrapondo estes reclusos temos (14) reclusos que afirmaram não sentir grandes dificuldades de adaptação: "Não senti muitas, não é a primeira vez que estou preso..." (E8); Apesar de tudo (...) pensava que a prisão fosse pior, "afinal não é assim tão mau como julgava, pensei que fosse pior!” (Entrevista caso 9). 
Relativamente à subdimensão das alterações na sua maneira de ser/estar neste período de transição, verifica-se que (14) reclusos afirmam ter sentido alterações: "Mudei bastante, sobretudo no que toca aos consumos. Agora penso curar-me e livrar-me do vício de vez" (E13); "Eu era um miúdo, não pensava bem no que fazia! Agora penso melhor nas coisas". (E18); verifica-se também que (9) reclusos sentiram alterações na sua maneira de ser, mas estas foram apenas parciais: "Alterei um bocado...sobretudo a nível de encarar a vida, valorizar aquilo que temos no agora" (E10); Agora penso muito mais no que fiz, tenho que pensar mais em mim" (E21); conclui-se também que existem (7) reclusos que declaram abertamente que durante este período de transição não ocorreu qualquer tipo de alteração, que se mantém iguais ao que eram antes do encarceramento: "Não considera que tenha havido mudanças na sua maneira de ser ou estar, refere que é do seu temperamento ser muito reservado e calado, o facto de ter transitado de um meio livre para um meio fechado não alterou a sua postura em nada" (Entrevista caso 4); “Não houve alterações. Quando saia de precária é que me metia muita confusão tanta liberdade! Era como ter todo o tempo do mundo e ao mesmo tempo não ter nenhum." (E7).

No que se refere à subdimensão dos factores facilitadores ao ajustamento e integração de cada recluso ao estabelecimento prisional, consideramos estes como uma parte integrante do ajustamento: o modo como recluso viveu a sua transição e reteve esta situação de encarceramento de modo a auxiliar o seu ajustamento. Uma vez que esta subdimensão se divide em mais que uma categoria, verificaram-se reclusos que apontaram mais que uma categoria/ factores facilitadores, dai que o seu número tenha ultrapassado o número da amostra. Assim, (14) dos reclusos-participantes apontaram os factores pessoais, declarando que neste período de transição e encarceramento o que ajudou ao seu ajustamento foi a sua postura e maneira de ser: "Factores pessoais por causa do meu feitio, de evitar conflitos" (E5); "Foi o factor pessoal, a maneira de ser ajudou a encarar melhor este castigo!" (E14). Verifica-se que (12) reclusos apontaram os factores sociais como facilitadores ao seu ajustamento e adaptação ao EP: Factor pessoal e o factor social - uma pessoa aqui vê quem são os seus amigos, aceita os primeiros concelhos e vê com quem pode contar!” (E21); “ (...) o factor social - conviver com o resto dos presos e dos guardas." (E24); um grande número de significativo de reclusos (19) apontou os factores académicos como os principais e significantes na facilitação do seu ajustamento à privação da liberdade: "factores académicos - o facto de estar ocupado permitiu-Ihe uma maior interiorização das regras, assim como maior facilidade na interacção com terceiros" (E1); "Acho que todos os factores ajudaram, sobretudo o factor académico, andar no curso ajudou bastante". (E4); "Factores pessoais não sou de andar atrás dos problemas e factores académicos, poder frequentar o curso e ajuda muito mais a passar o tempo!". 
(E8); apenas (6) reclusos apontaram os factores institucionais como facilitadores do seu ajustamento à prisão: o modo como a abordagem aos reclusos no seu acolhimento e no posterior acompanhamento penitenciário facilitou a que estes reclusos se sentissem "bem acolhidos" e consequentemente bem "integrados": “(...) indica também os factores institucionais: o atendimento rápido e prestável de todas as entidades inerentes ao E.P. Declara que nunca lhe foi recusado nenhum atendimento e que quando solicita algo por norma é sempre assistido." (Entrevista caso 2); "No meu caso foram os factores académicos (curso) e os da instituição - ocupação laboral”. (E15). Apenas (1) recluso referiu que não sentiu nenhum factor facilitador da sua integração: Quando confrontado se no seu caso em concreto tinham surgido factores facilitadores de integração e ajustamento ao E.P refere que não, a nenhum nivel. Refere que a falta de cursos e de actividades foram as principais barreiras à sua integração, uma vez que ficava com "excesso de tempo livre a remoer" (E20).

Relativamente à categoria: Sentimento de Reinserção Social, quisemos verificar até que pontos os reclusos sentem que estão a ser preparados para serem reinseridos novamente na sociedade. Concluímos que (19) reclusos afirmaram que sim: "Sim, estar aqui já é mais que castigo para nos ensinar..." (E25); contrariando este sentimento, encontramos (11) reclusos que afirmam não sentir que estão a ser preparados para serem reinseridos novamente na sociedade enquanto cidadãos livres: "Sinceramente, nada..." (E6).

Na categoria desta dimensão Transição e Ajustamento ao EP, surge-nos a categoria: Sugestões de Reinserção Social para os futuros ex-reclusos. Verifica-se então, que da nossa amostra de 30 reclusos, (3) reclusos sugeriram que para melhor reinserção a condescendência de saídas precárias com maior regularidade: "Mais oportunidade de sairmos lá para fora, mais saídas precárias e mais emprego lá fora" (E15); concluímos também que (6) reclusos fazem sugestão de maior apoio social que os reclusos deveriam ter aquando da sua libertação: "Deviam arranjar habitação para aqueles que não têm, mais apoio social e económico." (E19); (11) reclusos sugerem também maiores oportunidades de trabalho e inserção dos futuros ex-reclusos em empregos no exterior: "Mais oportunidade de trabalhar lá fora para nos habituarmos. Se for tudo de uma vez, ainda corre mal...podemos cair em tentação mais facilmente!" (E11); (4) reclusos fazem referência à ocupação laboral que deveriam beneficiar na altura da libertação: “ (...) sugere também que deveriam prestar mais apoio nas questões laborais, arranjar oportunidades de emprego para aqueles que estivessem prestes a sair em liberdade" (E24); outros (4) reclusos referem os tratamentos que deveriam ter na altura da libertação, sendo estes tratamentos inerentes aos consumos de estupefacientes ou tratamentos do acompanhamento psicológico: "deveriam preparar as pessoas aos poucos para serem restituídas à liberdade, sobretudo a nível de apoio psicológico" (Entrevista 
caso 13); apenas 2 reclusos referem que não é preciso fazerem "nada" porque já fazem tudo por eles: “Acho que já fazem tudo, o resto vem de nós!” (E23).

Quanto à sexta dimensão: Projectos Futuros e Resiliência, as principais questões retiradas da entrevista foram: Quais são os seus projectos futuros? (A nível familiar, relacionamentos interpessoais, a nível profissional, etc.). Quais são os investimentos que está a fazer para o seu futuro? Como classificaria a sua motivação no processo da sua futura reinserção?

Tabela 7: Sexta Dimensão: Projectos Futuros e Resiliência

\begin{tabular}{|c|c|c|c|}
\hline Dimensão & Subdimensão & Categoria & Frequência \\
\hline \multirow{6}{*}{$\begin{array}{l}\text { Projectos Futuros \& } \\
\text { Resiliência }\end{array}$} & \multirow{2}{*}{$\begin{array}{l}\text { Projectos de vida fu- } \\
\text { turos e concretizáveis }\end{array}$} & Presentes & 15 \\
\hline & & Ausentes & 15 \\
\hline & \multicolumn{2}{|l|}{ Total } & 30 \\
\hline & \multirow{2}{*}{ Resiliência } & Alta & 9 \\
\hline & & Baixa & 21 \\
\hline & \multicolumn{2}{|l|}{ Total } & \\
\hline
\end{tabular}

Nesta dimensão Projectos Futuros e Resiliência, quisemos explorar até que pontos os projectos futuros da nossa amostra de (30) reclusos eram exequíveis e de que forma nos permitia inferir sobre a sua resiliência através das suas respostas dadas acerca dos projectos futuros.

Concluímos que metade dos reclusos (15) apresenta projectos exequíveis de se virem a realizar futuramente: "Quanto a projectos futuros, o recluso 30 revela-nos que tenciona reintegrar o agregado familiar e poder arranjar emprego para poder cuidar da sua família. Os investimentos que está a fazer actualmente passam pelo cumprimento da pena, mantendo-se ocupado e a frequência do curso. Receia em parte o futuro, pois não sabe o que o espera, mas não hesita em revelar que está motivado para ser reinserido novamente na sociedade e poder organizar novamente a sua vida." (E3O). Outra metade (15) dos reclusos a presenta projectos não muito crediveis relativamente à sua concretização e/ou revelam falta de empenho para a concretização dos mesmos: "Quero arranjar uma casa e tentar viver do R.S.I (Rendimento Social de Inserção) (E21);“Um futuro muito escuro...” (E21).

Quanto à subdimensão resiliência, esta foi avaliada no decorrer de toda a entrevista, com especial incidência nas respostas dadas acerca dos projectos futuros. Deste modo, (11) reclusos apresentaram respostas que confirmam ter uma resiliência elevada: "Diz que quando for restituído à liberdade tenciona reingressar o agregado familiar, viver com os pais e continuar a trabalhar na sua empresa. Declara que mesmo estando preso está a fazer investimentos no seu futuro, a nivel profissional, estando sempre em reuniões para fazer prosperar o seu negócio. Daqui a 10 anos espera ter-se tornado muito melhor pessoa, referindo que está 
muito motivado para se reinserir futuramente na sociedade." (E10); Contrapondo estes surgem-nos (21) reclusos cujos planos futuros não são muito confiáveis na sua execução, nem demonstram ter consistência e maturidade suficientes na sua resiliência: “Apesar de não pensar muito no que vai fazer quando sair da prisão, declara que já está a fazer alguns investimentos no seu futuro, nomeadamente a formação que teve na área da jardinagem, assim como na área da barbearia. Espera quando sair ter uma vida melhor, ter um relacionamento estável e funcional com a família, estar bem integrado na sociedade com um emprego estável. Pretende porventura emigrar" (E5).

\section{Discussão dos resultados}

Uma vez apresentados e analisados os dados obtidos com o estudo, iremos de seguida, proceder à discussão dos mesmos, através do seu confronto com outros estudos, investigações realizados.

Apesar da ausência de trabalhos e investigações de trabalhos idênticos relativos à transição e ajustamento dos reclusos ao Estabelecimento Prisional, tentamos abordar um conjunto de estudos e modelos teóricos que não estando na sua totalidade relacionados com este temática, serviram de suporte e fundamento.

Assim, este estudo assenta na diversidade e complexidade de transições e processos de adaptação da teoria de Schlossberg, Waters e Goodman (1995) para determinar e analisar a identificação da transição dos reclusos, os factores determinantes das respostas às transições e o potencial dos recursos individuais de cada recluso. A identificação de uma transição assenta no reconhecimento da sua natureza, o que posteriormente irá condicionar o modo como lidar com a situação. Partindo desta ideia, a primeira transição por nós considerada, foi a primeira reacção aquando da entrada da prisão e o facto de ser primário e/ou reincidente: mais de metade dos reclusos (18) refere ter sentido grande angústia e receio nesta primeira identificação da transição, havendo registo de pelo menos, (8) reclusos que refere ter tido uma reacção "boa"; nesta ordem de ideias, também se verifica na nossa amostra que temos (16) reclusos primário vs (14) reclusos reincidentes.

No segundo estudo realizado por Gonçalves (1995-1997) este classifica uma boa adaptação à prisão consoante um conjunto de variáveis. As que se distinguem mais são a condenação, o tempo de prisão cumprido e o factor primário vs reincidência: assim, Gonçalves (1995-1997) concluiu que a condenação não surte efeitos no modo como o recluso se adapta à prisão, mas sim a forma como ele interpreta e vivencia esta experiencia; o tempo de prisão cumprido assenta na ideia de que os processos adaptativos sofrem modificações à medida que decorre a reclusão; 
o facto de ser primário ou reincidente não tinha diferenças significativas uma vez que um recluso pode ser reincidente e simultaneamente "bem adaptado". O que importa realçar aqui é então o modo como cada recluso vivencia a experiência e a transição, não tanto as variáveis jurídico-penais.

Uma vez identificada a transição (primeira reacção ao contacto com o estabelecimento prisional) passaremos agora à análise dos vários elementos ou factores que influenciam o modo como cada recluso lida com esta transição: situação, eu, suporte, estratégias.

Relativamente à caracterização da Situação perante a prisão, mais de metade (16) sentiram dificuldades de integração à instituição aquando da sua detenção, justificando-se com as dimensões reduzidas das celas, do espaço "fechado", da rigidez das regras e horários inerentes ao sistema fechado. Mas há medida que o tempo ia passando, muitos destes reclusos afirmavam que se iam adaptando aos poucos, estando actualmente bem "adaptados". Schlossberg, Waters e Goodman (1995) na sua teoria fazem também referência que a durabilidade de cada transição e percepção do mesmo, ao controlo que temos ou não da situação, à existência ou não de experiencias anteriores e à própria avaliação que o indivíduo faz da situação condiciona o modo como cada indivíduo encara e vive a transição.

Em relação ao recurso potencial Eu (Self), verifica-se que na nossa amostra dos 30 reclusos houve bastantes alterações na sua maneira de ser e estar neste período de privação da liberdade: (23) reclusos afirmaram sentir alterações (presentes e parciais). Muitos afirmam que sentiram maior sentido de responsabilização, quer para com eles, quer para com a sua família, fazem também referência ao facto que modificaram a maneira de ser, sobretudo a nível de encarar uma nova motivação para realizarem um programa de desabituação de estupefacientes e consequentemente levar a bom termo a abstinência. Como referiram Schlossberg, Waters e Goodman (1995) as transições podem variar consoante as características pessoais e recursos psicológicos de cada indivíduo. Assim, um número significativo de reclusos referiu alterações na sua maneira de ser o que também se poderá dever ao desenvolvimento e maturidade alcançados por cada recluso neste período de transição. Este recurso potencial do Eu (Self) também pode ser verificado através da subdimensão da Resiliência avaliada na dimensão Projectos Futuros e Resiliência, em que se verifica que um número significativo de reclusos (21) não reúne condições necessárias à sua resiliência, no sentido que as respostas apresentadas não nos confirmaram que irão alterar os seus estilos comportamentais. Freitas e Downey (1998) no seu estudo sobre a resiliência fazem alusão às variáveis preditivas sobre o uso das capacidades individuais e na forma como estas influenciarão a capacidade de cada individuo na resolução dos seus problemas, sendo os projectos futuros uma dessas variáveis. 
Relativamente ao recurso potencial Suporte, verifica-se que esta transição e este acontecimento do encarceramento são também fortemente condicionados e influenciados pelo tipo de suporte social que cada recluso tem. Analisamos este tipo de suporte intra-muros (relacionamentos dentro da própria instituição) e no exterior (a nível familiar). Assim concluímos que um grande número de reclusos afirmam ter suporte social intra-muros (25) reclusos podem contar sempre com alguém caso seja necessário - segundo Schlossberg, Waters e Goodman (1995), estes suporte sociais das transições tem como função ajudar o individuo a lidar com a mudança e com a situação em si, segundo Caplan (1976; cit in Schlossberg, Waters \& Goodman, 1995) este suporte proporciona e ajuda a mobilizar recursos de protecção e estratégias de modo a ajudar o individuo a superar a situação da melhor maneira. A nível familiar, verificamos que (26) reclusos afirmam ter apoio e suporte familiar por um ou mais elementos, sejam eles, pais, irmãos, cônjuges e/ou outros familiares. Assim encarando a família como um sistema e um "todo", reconhecendo as suas dificuldades e regularidades, salientando as suas potencialidades e singularidades, o suporte que esta dá ao indivíduo recluso é fundamental para a forma como este lida com o encarceramento e o tratamento penitenciário. Santos Silva (2001) defende também esta ideia ressalvando a importância que as redes sociais têm no tratamento dos toxicodependentes que se poderá alastrar a outros domínios, como é o caso dos reclusos-toxicodependentes.

Ao nível do recurso potencial relativo às Estratégias, consideramos estas os factores facilitadores de integração e ajustamento que os reclusos apontaram facilitar o seu ajustamento: factores pessoais - maneira de ser, personalidade, feitio; factores sociais - encarar o convívio e interacção entre os outros reclusos como forma de facilitar a integração e o cumprimento de pena; os factores académicos - frequência de cursos e formação que podem ajudar, não apenas a ocuparem o tempo de maneira saudável e produtiva, mas também aquisição de novos conhecimentos e aptidões; factores institucionais - abordagem que a própria prisão faz ao acolher estes indivíduos e a forma como eles sentem esse acolhimento, através da ocupação laboral. Assim, (19) reclusos apontaram os factores académicos, e (6) reclusos apontaram os factores institucionais como possiveis estratégias e factores facilitadores de lidar com o cumprimento de pena e o encarceramento em si - nestes factores estão incluídas as formações, a escola, os cursos, assim como as ocupações laborais que a instituição oferece. Outra estratégia apontada passa pelos factores sociais: interacção constante com os restantes reclusos. Perarlin et al. (1978, cit in Schlossberg, Waters \& Goodman, 1995) definem estratégias de coping como respostas que modificam a situação, respostas de controlo do significado do problema, respostas que ajudam a gerir o stress após a transição. Cada caso é um caso, cada recluso é uma nova transição para compreender, daí que diferentes reclusos tenham diferentes abordagens e 
visões das mudanças e transições, o que também irá contribuir para a variação de respostas de controlo do significado da transição.

Giles et al. (2004) e Vacca (2005) confirmam estas estratégias para lidarem com o encarceramento, mas também para evitar o risco de reincidência. Carter (2008) defende também esta ideia e estratégia, a inserção e ocupação laboral incutem no indivíduo respeito pelas normas o que irá desencadear um maior sentido de responsabilização e vontade de se reintegrarem futuramente.

Relativamente ao estado de saúde, verificamos na apresentação dos resultados que mais de metade da nossa amostra assumia hábitos de consumo no exterior, mais concretamente (22) reclusos. Quanto aos tratamentos, um número significativo de reclusos encontra actualmente a realizar tratamentos (12) ou já realizou no passado (10). Tal como afirmou Silva Santos (2001), a prevenção e a intervenção realizadas dentro dos estabelecimentos prisionais podem servir futuramente como tratamento para a reinserção. Isto também terá repercussões na forma como o recluso se ajustará ao estabelecimento, assim como na sua resiliência futura.

\section{Conclusão}

Este estudo sugere que a adaptação e o ajustamento do recluso ao estabelecimento prisional são pautados por inúmeros factores. Procuramos através de uma investigação qualitativa, mais concretamente através da análise de conteúdo das entrevistas elaboradas anteriormente responder a todas as questões inicialmente propostas. Assim após a elaboração do guião da entrevista, na qual foi construída mediante dimensões para permitir uma abordagem mais completa aos temas que nos interessavam, procedeu-se à escolha da nossa amostra (uma escolha intencional ou não probabilística, porque como explicado anteriormente, foram escolhidos reclusos providos de determinadas características para análise de estudo).

Verificamos que havia diferenças quanto as dimensões abordadas no modo como cada recluso transita de um meio livre para um meio fechado e o modo como se ajusta ao estabelecimento prisional, a saber: o seu estado de saúde, a abordagem que cada recluso sente que a própria instituição faz no seu acolhimento, as características individuais de cada um, a sua historia e situação familiar, estratégias adoptadas no tempo de encarceramento e a resiliência de cada apoiada nos planos futuros que apresentaram.

Assim, na dimensão do estado de saúde e situação familiar segundo Santos Silva (2001) encarando o tratamento como modo de reinserção e apostando nas redes sociais, os reclusos adoptam outra postura face ao período de privação e 
consequentemente ao tempo de cumprimento de pena. Claro que se deverá que ter em conta a vontade do recluso, assim como as características individuais de cada um, os gostos, as necessidades, o contexto onde ocorre e que condiciona aplicação da intervenção.

238 Nas dimensões Situação Familiar e Suporte Social Intra-Muros também se verificam diferenças significativas, nomeadamente, a nível da frequência e qualidade das relações vinculativas quer no exterior com a família, quer institucional (intra-muros). Confrontando os resultados da nossa investigação com a revisão da literatura anterior, tanto Clemmer (1940) e Comfort (2007) confirmam que a manutenção dos laços familiares e qualidade desses mesmos laços é um forte factor condicionante da adaptação do recluso ao estabelecimento e posterior ajustamento. Deste modo, não apenas para ajudar o recluso a fazer uma "boa transição" ao estabelecimento prisional, seria importante apostar na intervenção sistémica e familiar com as famílias dos reclusos, uma vez que estas têm um papel tão importante na forma como o recluso vive o quotidiano prisional.

Relativamente à dimensão Prisão Actual e Transição e Ajustamento ao Estabelecimento Prisional, verifica-se que não existem diferenças significativas relativamente à condição primário versus reincidente, o que também foi comprovado pelo primeiro estudo realizado por Gonçalves em 1988-1992 (cf. Gonçalves, 2000): não importa verdadeiramente se o recluso já tinha adoptado anteriormente uma conduta delituosa ou não, mas o modo como vivencia e experiencia esta transição e ajustamento. Quanto à subdimensão Factores Facilitadores de Integração, verificamos que a maioria apontou os factores académicos e os factores sociais, ou seja, utilizaram como estratégia de transição (o recurso Strategies da teoria de Transição de Nancy Schlossberg) a ocupação (quer laboral, quer académica) e o convívio com os restantes reclusos no cumprimento das normas institucionais sem contudo perderem o seu "eu" individual durante este período de encarceramento. Verifica-se a existência de momentos críticos de transição na vida destes sujeitos, mas para um melhor compreensão desde fenómeno e consequente adaptação às mudanças seria necessária uma abordagem mais ecológica. A dimensão deste estudo apesar de ser reduzida serviu para tentar conciliar os factores da teoria dos 4 S's com a transição e ajustamento que cada um dos nossos trinta reclusos sentiu (e sente) e experienciou (e ainda experiencia). Não devemos fazer qualquer tipo de generalização dos resultados, uma vez que a natureza deste estudo (investigação qualitativa) conta sempre com a percepção e opinião individual de cada um, podendo a mesma resposta ser condicionada por diversos factores: meio, características individuais.

Seria interessante avançar para estudos mais representativos da população prisional sobre a transição e ajustamento dos reclusos aos estabelecimentos 
prisionais, contribuindo para um conhecimento mais sustentado e consequente desenvolvimento de programas de intervenção mais adequados aos reclusos em contextos tão particulares, como são os Estabelecimentos Prisionais.

\section{Referências}

Born, M. (2003). Psicologia da Delinquência. Lisboa: Climepsi Editores

Carter, F.C. (2008).Offender Employment is the key. Corrections Today.

Clemmer, D. (1940). The prison community. New York: Holt.

Comfort, M. (2007). «Partilhamos tudo o que podemos»: a dualização do corpo recluso nos romances através das grades. Análise Social, vol. XLII (185), 1055-1079.

Cunha,M. (1994). Malhas que a reclusão tece: questões de identidade numa prisão Feminina. Lisboa: Gabinete de Estudos Jurídicos Sociais do Centro de Estudos Judiciários.

Feisher, M.S. \& Decker, S.H. (2000). Going Home, Staying Home: Integrating Prison Gang Members into the Community. Corrections Management Quarterly, 2001, 5(1), 65-77

Foucault, M. (1987). Vigiar e Punir: Nascimento da Prisão. Petrópolis:Vozes.

Freitas, A.L. \& Downey, G. (1998). Resilience: A dynamic perspective. International Journal of Behavioral Development. 22 (2), 263-285

Giles, M., Tramle A., Allan, M., Less, C., Larsen, A. \& Bennet, L. (2004). To train or not to train: The role of education and training in prison to work transitions-Support document. National Centre for Vocational Education Research: Australian National Training

Gilmore, T. \& McCann,J.E. (1982). Designing effective transitions for new correctional leaders. Policy Studies Review, Vol.2, n. ${ }^{\circ}$.

Goffman, E. (1992). Manicómios, prisões e conventos. São Paulo: Perspectiva.

Gonçalves R.A. (2008). Delinquência, Crime e Adaptação à Prisão. $3^{\text {a }}$ edição. Coimbra: Quarteto Editora

Gonçalves, R.A. \& Vieira, S.(2005). Atitudes face aos reclusos em guardas prisionais: Implicações para a formação do pessoal penitenciário. Temas Penitenciários, Série III, 1 e 2, 23-28

Gonçalves, R.A. (1999). Psicopatia e Processos adaptativos à Prisão. Instituto de Educação e Psicologia, Centro de Estudos em Educação e Psicologia da Universidade do Minho

Gonçalves, R.A. (2007). Promover a mudança em personalidades anti-sociais: Punir, tratar. Análise Psicológica., 4 (XXV), 571-583

Jorge, A.M. (2005). O Processo de Transição de Alunos Surdos para o Ensino Superior. Dissertação de mestrado não publicada. Coimbra: Universidade de Coimbra.

Leibowitz, Z.B. \& Schlossberg, N.K. (1982). Critical Career Transitions: a Model for designing Career Services. Training and Development Journal.

Lourenço, M.M.J. (2005). A família como factor de socialização em meio prisional: estudo exploratório no estabelecimento prisional regional de Vila Real. Dissertação de Mestrado não publicada. Universidade Fernando Pessoa.

McCord, J. (2002). Forjar Criminosos na Família. In Fonseca, A.C. (Ed). Comportamento AntiSocial e Família - Uma abordagem Científica. Coimbra: Almedina.

Pais, J.M. (1991). Formas Sociais de Transição para a vida adulta, os jovens através dos seus quotidianos. Lisboa: ISCTE. 
Ramos, E.L.V. (2006). A formação de educadores especializados em âmbito penitenciário, na perspectiva da pedagogia social. Revista Portuguesa de Educação, 19 (1), 129-152.

Rauter, c. (2007). Clínica e Estratégias de Resistência: perspectivas para o trabalho do Psicólogo em Prisões. Psicologia \& Sociedade; 19 (2), 42-47

Ribeiro, J.L.P. (2007). Metodologia de Investigação em Psicologia e Saúde. Porto: Legis Editora.

Rogers, C. R. (1961). Tornar-se Pessoa. Lisboa: Moraes Editores

Schlossberg, N.K. (1981). A model for analysing human adaptation to transition. Counseling Psychology, 9, 2-18.

Schlossberg, N.K., Waters, E.B. \& Goodman, J. (1995). Counseling Adults in Transition: Linking Practice with Theory. New York: Springer.

Silva, J.A.S.(2001). As redes sociais e o percurso na toxicodependência. O Tratamento como instrumento de Reinserção. Toxicodependências, Vol, 7,n. ${ }^{\circ} 1$.

Silva, P. R. (2007). Recursos psicológicos na transição do ensino superior para o mercado de trabalho - um estudo exploratório. Dissertação de Mestrado não publicada. Faculdade de Psicologia e Ciências da Educação, Universidade de Coimbra

Soares de Melo, R.A. (2002). Os Quês e os Porquês da Prevenção Primária da Toxicodependência. Toxicodependências, Vol. 8, n. $^{\circ} 2$.

Thompson, J. (2000). Bewilderment: preparing prisoners for "real" work in the fictional world of prison. Community, Work \& Family, Vol. $3, n .^{\circ} 3$.

Vacca, J.S.(2004). Educated Prisoners Are Less Likely to Return to Prison. The Journal of Correctional Education, 55 (4).

Visher, C.A. \& Travis, J. (2003). Transitions from prison to community: understanding pathways. The Annual Review of Sociology. 29:89-113.

\section{Transition and adjustment of inmates to prison}

The prisoner system and its processes is still a theme with lack of search and few discussed in our country. We are starting to give the first steps in the comprehension, as in punishment system and integration in its own meaning, as also trying to understand the dynamics involved: the inmate, the adaption of this one, impolite behaviour, anti-social personality, the crime, the punishment.

The following investigation, by a qualitative boarding tried to understand the perceptions and opinions in a set of inmates about their experiences of life in the transition from liberty to prison. The analysis also tried to know the different adjustment that each one made. By a script of interviews half structured, tried to analyse six big areas (health status, familiar situation, social intra-prison situation, actual prison, transition, adjustment, future projects and resilience) and also living habits of each one in these areas.

The main conclusion is that each profile is a profile, and to infer about the inmate's belief we have to consider some factors, between of some, familiar situation, institutional factor, each ones characteristics, the development history, which crime, the opinion that each prisoner has about himself and the sentence living. Only 
after of an analysis and total understanding to "Self" we are able to comprehend the prisoner in its own and his adjustment to prison.

KEY-WORDS: prison, adjustment, transition, inmates.

\section{Transition et d'adaptation des détenus à la prison}

Le système pénitentiaire et les processus qui lui sont inhérents sont encore un sujet relativement peu exploré et a grandi dans notre pays, commencent à prendre les premières mesures dans la compréhension non seulement de punir et de resocialisation, mais cherche également à comprendre la dynamique en cause: le recluse, cette adaptation, la délinquance, la personnalité antisociale, le crime, la punition. Cette recherche visait à travers d' une approche qualitative pour mieux comprendre les perceptions et les opinions d'un groupe de prisonniers de leur expérience de vie au milieu d'une transition vers une moitié libre ajustement totalitaire et différencié que chaque détenu a fait. Grâce à une série d'entretiens spécifiques et semi structurées, nous avons essayé d'analyser les six principales dimensions (l'état de santé, situation de famille, le soutien social intra-prison, aujourd'hui, la prison, de transition et d'ajustement, les projets futurs et de la résilience) et les expériences de chaque détenu dans ces dimensions. Nous avons constaté que chaque cas est unique, et d'interpréter l'avis de chaque détenu doit tenir compte de divers facteurs, y compris le facteur familial, facteur institutionnel, les caractéristiques individuelles de chacun, l'histoire du développement, le type de crime, la perception que chaque prisonnier a le droit, la phrase. Ce n'est qu'après une analyse et une approche globale de "Soi», que c'est que nous essayons de comprendre l'individu dans son ensemble et son adaptation à la prison.

MOTS-CLÉS: prison, adaptation, transition, détenus. 